\title{
EFFECTS OF CASSIA SIEBERIENA LEAF EXTRACTS ON THE INTESTINAL MOTILITY OF RAT
}

\author{
${ }^{*}$ R.O. AKOMOLAFE ${ }^{1}$; I.O.ADEOSHUN ${ }^{1}$; A.A. ELUJOBA ${ }^{2}$; E.O. IWALEWA ${ }^{3}$ AND A.O.AYOKA ${ }^{1}$. \\ ${ }^{1 * D e p a r t m e n t s ~ o f ~ P h y s i o l o g i c a l ~ S c i e n c e s ; ~ P h a r m a c o q n o s y ; ~ a n d ~}{ }^{3}$ Pharmacology, \\ Obafemi Awolowo University, Ile-Ife, Nigeria .
}

\begin{abstract}
The in-vitro effects of methanolic extract (MCSL) and aqueous infusion (ACSL) of the leaves of C. sieberiena on the motility of the rat intestines were studied and compared with those of $C$. acutifolia (MCAL and ACAL) "Senna". All the extracts and infusion relaxed the ileum dose-dependently. Their effects were blocked by tolazoline, indicating that $\alpha$-adrenergic receptors were involved. MCSL contracted the colon dose-dependently and was blocked by atropine $\left(1.7 \times 10^{-8} \mathrm{M}\right)$ and nifedipine $\left(2.8 \times 10^{-10} \mathrm{M}\right)$. ACSL contracted this segment at $2.0-8.0 \mathrm{mg} / \mathrm{ml}$ and relaxed it at $8.0-16.0 \mathrm{mg} / \mathrm{ml}$. Its relaxant effect was blocked by tolazoline $\left(1.0 \times 10^{-6} \mathrm{M}\right)$, indicating the involvement of $\alpha$ - adrenergic receptors. MCAL had a slight relaxant effect on the colon, while ACAL contracted it dose dependently and was blocked by promethazine $\left(3.1 \times 10^{-8} \mathrm{M}\right)$ and nifedipine $\left(2.8 \times 10^{-8} \mathrm{M}\right)$, indicating that $H_{1}$-receptor stimulation and increased intracellular calcium ion concentration are involved. MCSL was more potent than ACAL, while ACSL and ACAL were equipotent in contracting the colon. With proper processing $C$. sieberiena can be substituted for $C$. acutifolia.
\end{abstract}

Keywords: Cassia sieberiena , intestinal motility, anthraquinone glycoside

\section{${ }^{*}$ Corresponding author}

\section{INTRODUCTION}

Cassia sieberiena Linn (Leguminosae) is a medium-sized tree found in many parts of West Africa. Its leaves are compound. Its racemes are terminal, elongated and consists of yellow flowers (Watt and Breyer-Brandwijik, 1962). Fruit are greenish when fresh and brownish when ripe (Irvine 1961).

Folkloric evidence supports the use of Cassia sieberiena as laxative and purgative in many countries including Nigeria (Dalziel, 1937). Many scientific reports have been published validating the use of Cassia species in the treatment of constipation (Elujoba et al 1989, 1999; Abo et al 1999). Anthraquinone derivatives have been identified as the chemical constituents of Cassia species responsible for this therapeutic activity.

However there is not much evidence in literature about the physiological and pharmacological effects Cassia species on the intestine and the importance of the solvents used in their extraction. This work was carried out in order to examine the physiologic effects of the extracts of Cassia sieberiena leaves on the intestinal motility of rats in vitro with a view to promoting further understanding of their sites and mechanisms of action and the influence of extraction technique on their potency.

\section{MATERIALS AND METHODS Plant Materials}

The plant was collected from the campus of Obafemi Awolowo University, Ile-Ife in October 1998 and authenticated by Professor Elujoba of the Department of Pharmacognosy and Dr.H.Illoh of the Department of Botany of the University. Voucher specimen Number 14567 was kept in the Botany Department herbarium for reference purposes.

The leaves of the plant were dried in an oven at $50^{\circ} \mathrm{C}$ for ten hours after collection. This was to prevent enzymatic hydrolysis of the anthraquinone glycosides which usually occurs a few hours after collection and this hydrolysis is completed shortly afterwards thereby leading to loss of potency (Elujoba et al, 1989). The dried plant material was crushed with a GEC Grinding Machine (Christy and Norris Model) and was kept inside tight-fitting plastic containers at room temperature until ready for use.

Methanol Extract: $200 \mathrm{~g}$ of the crushed plant material was exhaustively extracted in a Soxhlet apparatus with methanol for 10 hours. 
The extract obtained was concentrated and evaporated at $40^{\circ} \mathrm{C}$ by using a rotary evaporator. The dried extract was weighed and then kept at $0^{\circ} \mathrm{C}$ until ready for use. Standard solutions of the extract were prepared by using distilled water as diluent.

Hot Infusion: $50 \mathrm{ml}$ of boiling distilled water was poured unto $5 \mathrm{~g}$ of the crushed plant material in a beaker. The mixture was allowed to stand for 30 minutes before it was filtered with a filter paper. An equivalent of $100 \mathrm{mg}$ dried plant material per $\mathrm{ml}$ aqueous infusion was obtained (Elujoba et al, 1999). Each infusion was always freshly prepared in order to prevent hydrolysis of the anthraquinone component of the plant during long storage.

Reference Drugs: Methanol extract and aqueous infusion C. acutifolia Senna, ("Herb Tea", Alpine Ltd. U.K.) were prepared in the same way as the leaves of $C$. sieberiena

Animal: Albino Wistar rats (200-300g) of either sex were obtained from the Animal House of the Faculty of Basic Medical Sciences, Obafemi Awolowo University. Each rat was starved for about 12 hours prior to the experiment, but was allowed to have free access to water. This was to ensure that the intestines were free of faecal materials (Akah et al. 1997).

The rat was killed by cervical dislocation and the intestines were quickly dissected out and freed from other connective tissues. They were placed inside a beaker containing aerated Tyrode solution: $\mathrm{NaCl} 136 ; \mathrm{KCl} 2.7 ; \mathrm{MgCl}_{2}$ 1.8; $\mathrm{CaCl}_{2} 1.8 ; \mathrm{NaHPO}_{4}$ 0.3; $\mathrm{NaHCO}_{3} 12.0$ and Glucose $5.6 \mathrm{mM}$ which was maintained at $37^{\circ} \mathrm{C}$. (Akah et al 1997).

Effects of Extracts and Antagonists on the Tissues: $2-3 \mathrm{~cm}$ of the required segment of the intestines was cut and mounted vertically inside a $20 \mathrm{ml}$ organ bath containing Tyrode solution which was maintained at $37^{\circ} \mathrm{C}$ by a thermostat-bearing heater and aerated with air from an aerator. The tension on the tissue was adjusted to $1 \mathrm{~g}$ in order to maintain its muscle tone. The tissue was allowed to equilibrate for one hour during which the tyrode solution was replaced at a ten minute interval.

Graded doses $(0.25-20.0 \mathrm{mg} / \mathrm{ml})$ of the methanol extract or infusion of the plant material were applied to the tissue and its responses were recorded by $a$ microdynanometer (Ugo Basile Model). Contact time of study was between 30 and 45 seconds, because the responses of the tissues in some cases were not immediate. The tissue was washed at least twice with fresh Tyrode solution after each dose to ensure that the tissue was free of the drug. The tissue was allowed to rest for between 10-15 minutes before the next dose of the extract or infusion was applied (Akah et al. 1997).

The dose of the extract which produced the maximum response was taken as the Working Dose against which graded doses of antagonists were tested. The tissue was always pretreated with the required dose of the antagonists for 3 minutes before the application of the Working Dose of the extracts or infusions. Each antagonist was used until the dose which produced the maximum reduction in tissue response to the drugs was obtained. This dose was tested against the Working Dose in quadruplicate.

\section{RESULTS}

Percentage yields of the Methanol Extracts $(\mathrm{w} / \mathrm{w})$ of the plant and reference are as follows: Cassia sieberiena leaves (MCSL) $=24.7 \%$ Cassia acutifolia leaves "Senna" (MCAL) = $3.0 \%$

The methanol extract of $C$. sieberiena leaves (MCSL) contracted the colon in a dose dependent manner. Its effect was completely blocked by atropine $\left(1.7 \times 10^{-8} \mathrm{M}\right)$ and nifedipine $\left(2.8 \times 10^{-10} \mathrm{M}\right)$ (Fig 1). Its aqueous infusion (ACSL) had a biphasic effect on the colon; 2.0$8.0 \mathrm{mg} / \mathrm{ml}$ of the infusion contracted the colon, while $8.0-16.0 \mathrm{mg} / \mathrm{ml}$ of it relaxed this segment of the intestine. This response was blocked by tolazoline $\left(1.0 \times 10^{-6} \mathrm{M}\right)$ and was reduced to $50 \%$ by propranolol $\left(6.8 \times 10^{-8} \mathrm{M}\right)$ (Fig. 2). Both MCSL and ACSL relaxed the ileum dosedependently. Their effects were blocked by tolazoline $\left(1.3 \times 10^{-10} \mathrm{M}\right.$ and $1.0 \times 10^{-6} \mathrm{M}$ respectively) (Fig 3 and 4 ).

Methanol extract of $C$. acutifolia leaves (MCAL) or "Senna" produced very slight relaxant effects on the rat colon even at a dose as high as $40.0 \mathrm{mg} / \mathrm{ml}$ (Fig. 5). Its aqueous infusion (ACAL) contracted this segment dosedependently (Fig. 6). Its effect was completely blocked by promethazine $\left(3.1 \times 10^{-8} \mathrm{M}\right)$ and nifedipine $\left(2.8 \times 10^{-8} \mathrm{M}\right)$. MCAL produced contraction at a dose of $2.5 \mathrm{mg} / \mathrm{ml}$ and a dosedependent relaxant response on the rat ileum as from $5.0 \mathrm{mg} / \mathrm{ml}$ while the relaxant effects produced by ACAL was not very appreciable (Figs. 7 and 8). The effect of MCAL on this 
segment was blocked by tolazoline $\left(1.0 \times 10^{-9} \mathrm{M}\right)$ and drastically reduced by propranolol $\left(3.4 \times 10^{-}\right.$ $\left.{ }^{8} \mathrm{M}\right)$.

The doses of MCSL and ACAL which produces the maximum contractile response of the colon were $5.0 \mathrm{mg} / \mathrm{ml}$ and $8.0 \mathrm{mg} / \mathrm{ml}$ respectively (Figs.1 and 8 ), indicating that
MCSL was more potent than ACAL in contracting the colon. Both ACAL and ACSL produced maximum contractile response of the colon at $8.0 \mathrm{mg} / \mathrm{ml}$ (Figs.2 and 6), showing that both of them were equipotent in eliciting contraction of the colon.

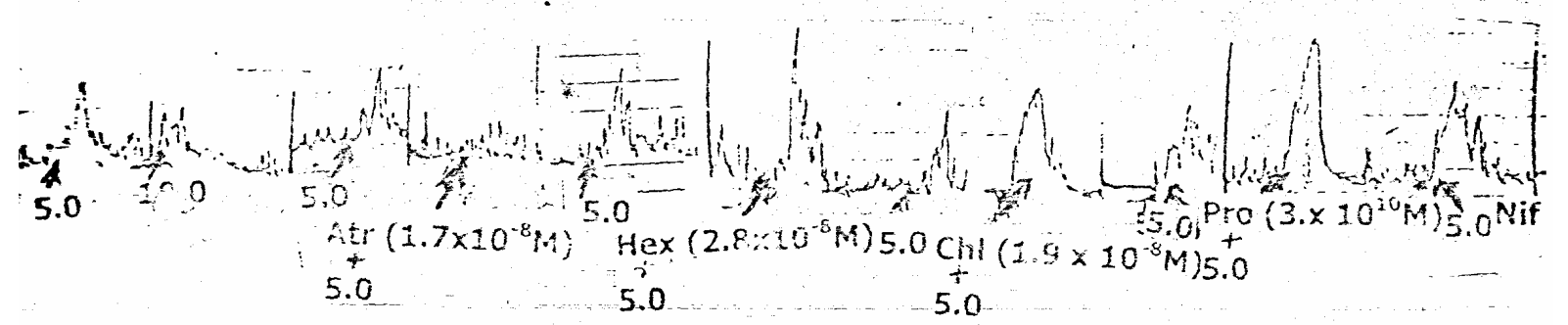

Fig. 1

Contractile effect of graded doses $(\mathrm{mg} / \mathrm{ml})$ of Methanol extract of $C$. sieberiena leaves on the rat colon. Effects were blocked by atropine $\left(1 \times 10^{-8} \mathrm{M}\right)$ and Nifedipine $\left(2.8 \times 10^{-10} \mathrm{M}\right)$.

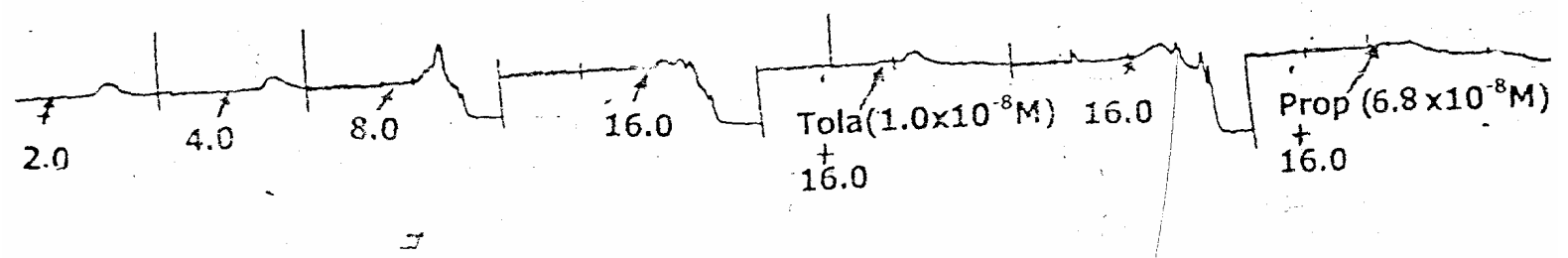

Fig. 2.

The biphasic effect of graded doses $(\mathrm{mg} / \mathrm{ml})$ of aqueous infusion of $C$. sieberiena leaves on the rat colon. $2.0-$ $8.0 \mathrm{mg} / \mathrm{ml}$ of the infusion contracted the colon, while $8-16 \mathrm{mg} / \mathrm{ml}$ relaxed it. Tolazoline $\left(1 \times 10^{-6} \mathrm{M}\right)$ blocked its relaxant effects.

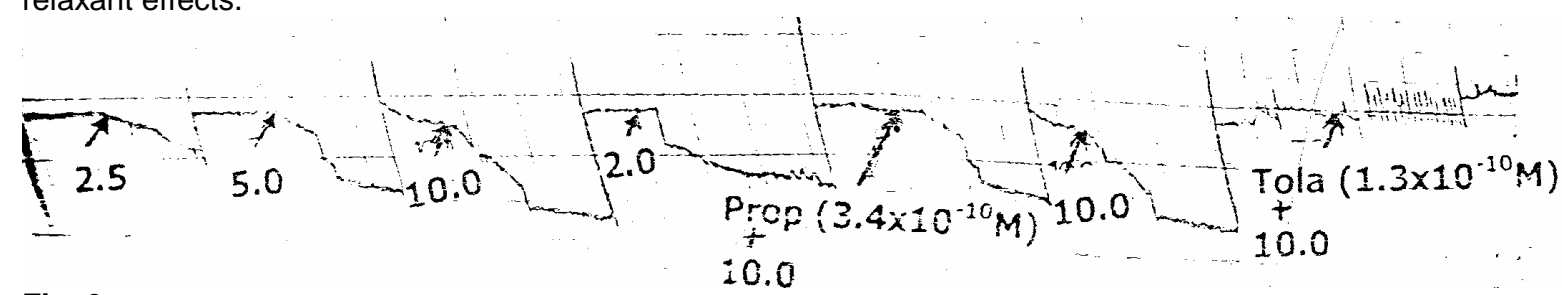

Fig. 3

Relaxant effect of graded doses $(\mathrm{mg} / \mathrm{ml})$ of Methanol extract of $C$. sieberiena leaves on the rat ileum. Effect was blocked by tolazoline $\left(1.3 \times 10^{-10} \mathrm{M}\right)$.

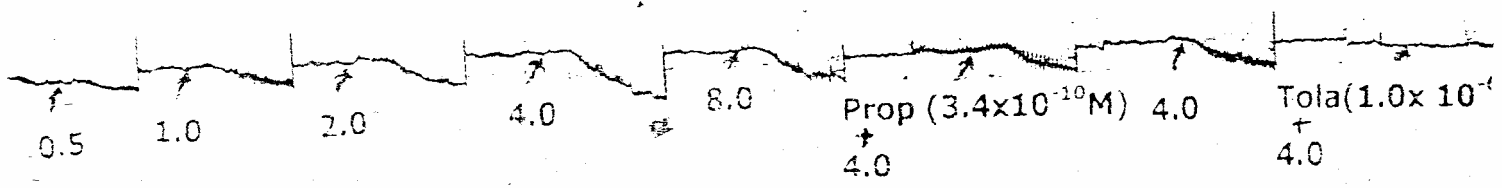

Fig. 4

Relaxant effect of graded doses $(\mathrm{mg} / \mathrm{ml})$ of aqueous extract of $C$. sieberiena leaves on the rat ileum. The dosedependent effect was blocked by tolazoline $\left(1.3 \times 10^{-10} \mathrm{M}\right)$.

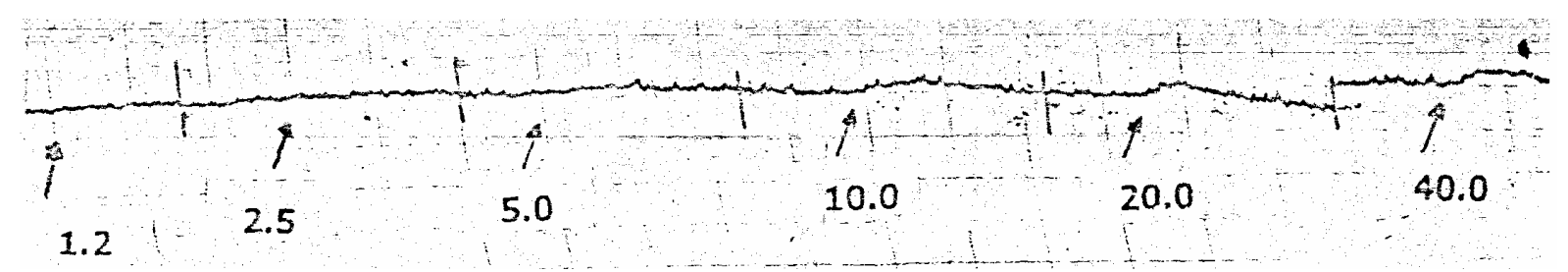

Fig. 5

Relaxant effect of graded doses $(\mathrm{mg} / \mathrm{ml})$ of Methanol extract of $C$. acutifolia leaves on the rat colon. 


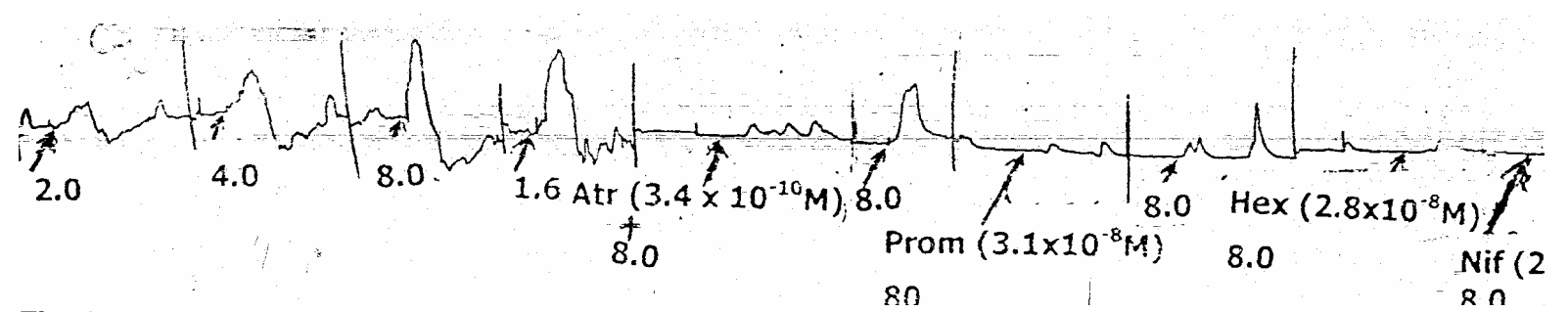

Fig. 6

The Contractile effect of graded doses $(\mathrm{mg} / \mathrm{ml})$ of aqueous extract of $C$. acutifolia leaves on the rat colon. Effects were blocked by promethazine $\left(3.1 \times 10^{-8} \mathrm{M}\right)$ and Nifedipine $\left(2.8 \times 10^{-8} \mathrm{M}\right)$.

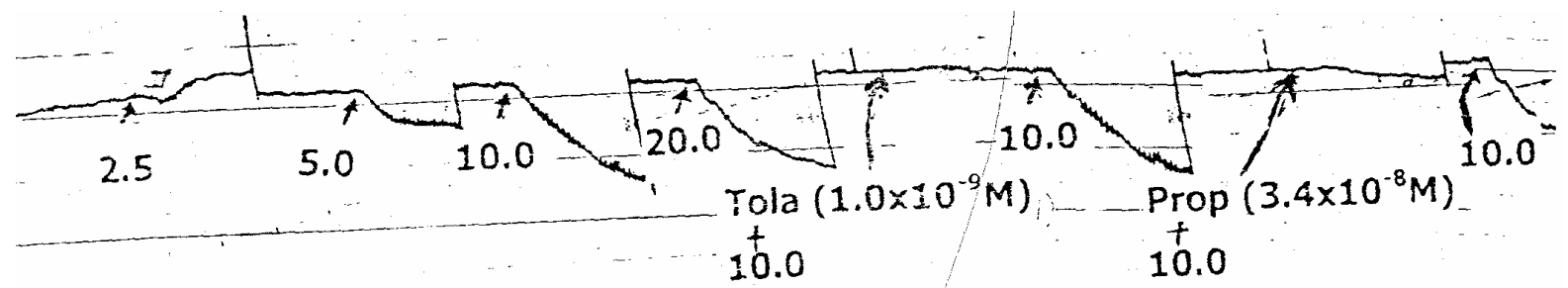

Fig. 7

The relaxant effect of graded doses $(\mathrm{mg} / \mathrm{ml})$ of methanol extract of $C$. acutifolia leaves on the rat ileum. The effect was blocked by tolazoline $\left(1 \times 10^{-9} \mathrm{M}\right)$.

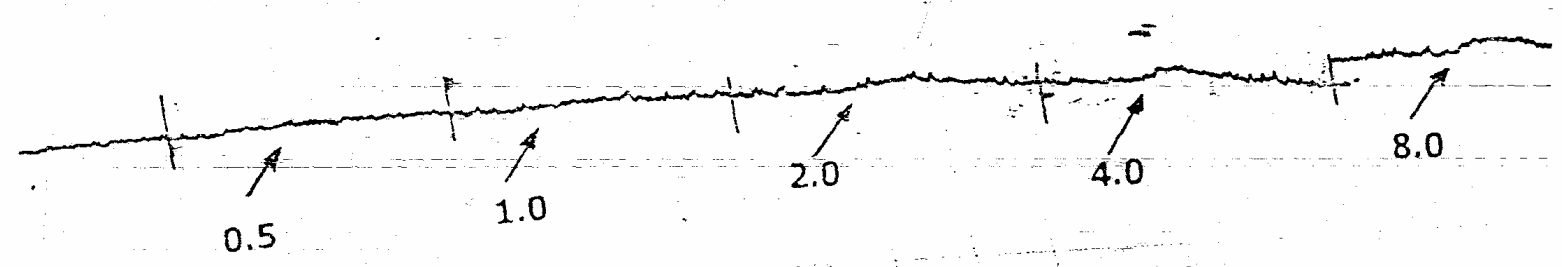

Fig. 8

The relaxant effect of graded doses $(\mathrm{mg} / \mathrm{ml})$ of aqueous infusion of $C$. acutifolia leaves on the rat ileum.

$10.0 \mathrm{mg} / \mathrm{ml}$ of both MCSL and MCAL produced maximum relaxant response of the ileum (Figs.3 and 7), indicating that they were equipotent in causing relaxation at this segment. $\quad 4.0 \mathrm{mg} / \mathrm{ml}$ of ACSL produced maximum relaxant response of the ileum (Fig.4), while $10 \mathrm{mg} / \mathrm{ml}$ of MCAL did the same at this segment (Fig.7), indicating that ACSL was more potent than MCAL in relaxing the ileum.

\section{DISCUSSION}

Methanolic extract of the leaves of $C$. sieberiena contracted the colon while its aqueous infusion had a biphasic effect on this segment of the gut, causing contraction at lower doses and relaxation at higher doses. This justifies the use of this plant as a laxative in folk medicine. This work also confirms that the site of the laxative action of this drug is the colon.

The active ingredients of Cassia species are anthraquinone glycosides, the sugar moiety of which makes the glycosides watersoluble, preventing them from passing from the lumen of the small intestine across the membranes into the blood stream. This explains why a significant amount of the glycosides would reach the large intestine to produce pharmacological action (Fairbairn, 1965).

If the anthraquinone glycosides are unable to cross the brush border of the small intestine, they cannot reach the intrinsic nerve plexus which is responsible for the motility of this segment. This plexus, Auerbach's plexus, located between the longitudinal and circular muscle layers of the gut must be stimulated by the anthraquinone glycosides to elicit contraction (Goodman and Gilman 1985).

Okada (1940) showed that when applied to the large intestine, free aglycones produce marked peristalsis while the anthraquinone glycosides had no effect till their sugar moiety was removed by hydrolysis. Okada (1940) further showed that this hydrolysis was effected by the enzymatic content of the large intestine, which were proved to be microorganisms, especially $E$. coli , peculiar to the colon (Fairbairn, 1965). This is in line with the findings of this work. The fact that the response of the tissue to the extracts was not 
immediate in some cases could also be due to the time required for the enzymatic hydrolysis of the glycoside to occur. This work also confirms that the laxative action of this drugs is due to stimulation of muscarinic receptor and the opening or activation of L-type calcium ion channels by their anthraquinone components.

Dewick (1997), reported that Senna is a stimulant laxative and acts on the wall of the large intestine by increasing peristaltic movement. After oral administration, the sennosides are hydrodysed by the intestinal flora into rhein anthrone, which appears to be the ultimate purgative principle on the large intestine. This probably accounts for the colonic contractile effect of its aqueous infusion observed in this study. Its methanolic extract produced no appreciable effect on the colon. Lemli (1985) indicated that the solvent used in extraction could have an effect on free radical formation by dimeric glycosides whose rate is determined by the substitution pattern of the bianthrones and is of much importance to their biological activity. Adverse alteration of the anthraquinone glycosides in the leaves of the plant by methanol could be the reason for their inactivity at the colon as observed in this study.

The relaxation of the ileum by those extracts and infusions which produced appreciable effects on the ileum is an indication of the fact that they contain some relaxant constituents which are yet to be identified, and which could also serve as antidiarrhoeal agents. The blockade of the effects of these relaxant constituents mainly by tolazoline is an indication that they act via adrenergic receptor stimulation.

The contractile effect of aqueous infusion of Senna on the colon was also blocked by promethazine, indicating that $\mathrm{H}_{1}$-receptor stimulation is involved in its action.

Methanolic extract of $C$. sieberiena leaves was more potent than aqueous infusion of $C$. acutifolia (Senna) in contracting the colon, while aqueous infusion of $C$. sieberiena and $C$. acutifolia are equipotent in eliciting the same effect. From this study, it could be concluded that, if more toxicological studies are carried out on $C$. sieberiena, its leaves could serve as a substitute for Senna, the official imported laxative drug.

In relaxing the ileum, the aqueous infusion of $C$. sieberiena leaves is more potent than methanol extract of $C$. acutifolia leaves, while the methanol extracts of the leaves of both plants are equipotent in eliciting the same response in the ileum. This is a further pointer to the possible use of the relaxant constituents of this plant as antidiarrhoeal agents, if finally isolated and characterized.

\section{REFERENCES}

Abo, K.A. Lasaki, S.W., Adeyemi, A.A. (1999) Laxative and antimicrobial properties of Cassia species growing in Ibadan Nigerian Journal of Natural Product and Medicine Vol. 03 p. 47-50.

Akah, P.A., and Oli, A.N. (1997) Preliminary Studies on Purgative effect of Carica papaya root extract. Fitoterapia Vol LXVIII No 4 P. 327 - 331.

Dalziel, J.M. (1937) The Useful Plants of West Tropical Africa. Grown agents for the colonies. London 612.

Dewick (1997) Medicinal Natural Products, A Biosynthetic Approach, published by John Wiley and Son Ltd, England P 56-62.

Elujoba, A.A., Ajulo, O.O., and Iweibo, G.O. (1989) Chemical and biological analysis of Nigeria Cassia species for laxative activity. Journal of Pharmaceutical and Biomedical Analysis 7:12 14531457.

Elujoba, A.A., Abere, A.T., and Adelusi, S.A. (1999) Laxative activities of Cassia pods sourced from Nigeria. Nigerian Journal of Natural Product and Medicine Vol 03 P 51 - 53.

Fairbairn, J.W. (1965) Chemical structure, mode of action and therapeutical activity of anthraquinone glycosides. Pharmaceutisch Weedkblad 100 14931499.

Goodman, L.S. and Gilman, A.A. (1970) The Pharmacological Basis of Therapeutics. The Macmillan Company $4^{\text {th }}$ Edition, pp $1020-1030$.

Lemli, J. (1986) The Chemistry of Senna. Fitoterapia Vol LVII No $133-40$.

Okada, T. (1940) Mechanism of the Cathartic action of Senna. Tohoku Journal of Experimental Medicine 38; $33-34$.

Watt, J.U. and Breyer-Brandwijik (1962). The Medicinal and Poisonous Plants of Southern and Eastern Africa Vol 1: 102 - 132.

Received: February 2003

Accepted in final form: August 2003 